\title{
Delineating bacterial community structure of polluted soil samples collected from cancer prone belt of Punjab, India
}

\author{
Gagandeep Kaur • Rohit Sharma $\cdot$ Kashmir Singh • \\ Pushpender K. Sharma
}

Received: 8 October 2014/ Accepted: 13 December 2014/Published online: 7 January 2015

(C) The Author(s) 2015. This article is published with open access at Springerlink.com

\begin{abstract}
S rRNA gene analysis has emerged as one of the valuable tools that are being utilized in investigating the molecular phylogenetic structure of the particular environment. Here, we embarked upon understanding and delineating the molecular phylogeny structure of microbes in polluted soil samples from cancer prone belt of the Punjab, India, which is highly contaminated with herbicide, pesticide and heavy metals. To investigate the bacterial phylogeny structure, a high-molecular weight metagenomic DNA was extracted from the soil samples, followed by PCR amplification, cloning and analysis of the $16 \mathrm{~S}$ rRNA genes. Study employing $16 \mathrm{~S}$ rRNA profiling of the community DNA revealed the presence of two major phylums: the Proteobacteria (26.7\%), the Bacteroidetes $(11.2 \%)$, and several minor groups, i.e., Acidobacteria (4.2\%), Actinobacteria (4.2\%), Firmicutes (2.8\%), Verrucomicrobia (2.8\%), Gemmatimonadetes (1.4\%) and Chloroflexi (1.4\%). Among the Proteobacteria, we mainly observed the $\alpha$-Proteobacteria (18.3\%). Nearly, $38 \%$ of the recovered $16 \mathrm{~S}$ rRNA gene sequences in this study do not share similarity with known culturable bacterial sequences reported in the genebank data base and hence considered to be novel. More interestingly, 16S rRNA gene
\end{abstract}

G. Kaur and R. Sharma contributed equally.

G. Kaur · P. K. Sharma $(\bowtie)$

Department of Biotechnology, Sri Guru Granth Sahib World

University, Fatehgarh Sahib, Pb, India

e-mail: pushpg_78@rediffmail.com

R. Sharma

NABI, Mohali, Pb, India

K. Singh

Department of Biotechnology, Panjab University,

Chandigarh, India sequences of archaeal origin (7.0\%) were also recovered that primarily indicate change in their evolution pattern. A phylogenetic tree constructed based on alignment-dependent method revealed the extent of similarity these clones shared with each other, followed by alignment-independent methods that statistically confirmed the sequence variation among the clones. Despite the high level of contamination in the study area, we observed remarkable microbial diversity that mainly includes the Gram-negative bacteria. The presence of more Gram-negative bacteria indicates that they have evolved a robust mechanism to resist and cope up with these pollutants compared to Gram-positive groups. Investigation of the polluted soil samples employing culture-independent approach revealed important bacterial groups which could be engineered for future bioremediation studies.

Keywords 16S rRNA gene - Microbial diversity Molecular phylogeny $\cdot$ Soil $\cdot$ Bioremediation

\section{Introduction}

Soil is a superabundant yet under-characterized ecosystem that represents an intricate and inexhaustible source of microbial diversity. The complexity of microbial diversity in soil is accredited to diverse type of interacting parameters, such as $\mathrm{pH}$, water content, soil structure, climatic variations and biotic activity. The astonishing diversity of microbes present in the soil has immense potential in ameliorating our understanding about the soil microbial ecology. Furthermore, soil environment accommodates microbial species that can be a goldmine for the genes involved in biotechnological applications, such as biodegradation of man-made pollutants (Alexander 1977; Daniel 
2005; Diaz 2004). Hence, exploring the diversity of versatile soil microorganisms is of paramount importance foreseeing their applications in numerous disciplines of biology. However, most of the soil microorganisms are exceptionally well adapted to their environment, and cannot be cultured under the usual laboratory settings. Current estimate connotes that more than $99 \%$ of microorganisms present in their innate environment are not readily cultivable and, therefore, not accessible to applied and basic biotechnology research (Amann et al. 1995; Hugenholtz and Pace 1996; Ward et al. 1990). And hence, new and improved technologies are required to dissect the functional and structural diversity of the microbial species. Culture-independent approaches can circumvent such pitfalls and permit access to the genomes from entire communities that extend our comprehension about the diversity, ecology, evolution and functioning of the microbial world (Amann et al. 1995; Handelsman et al. 1998; Hugenholtz and Pace 1996; Riesenfeld et al. 2004; Ward et al. 1990).

The farmers in Punjab, India, are unseeingly using pesticides and chemical fertilizers to avert crop destruction, the extremity of these chemicals has resulted in extensive pollution of soil and water of Malwa region of the Punjab, due to which this region is experiencing the perilous repercussions, and has resulted in cancer and other dreadful diseases (Blaurock-Busch et al. 2014; Mittal et al. 2014). In the present investigation, we were aimed at studying the molecular phylogeny structure of the polluted soil samples of cancer prone belt of the Punjab, India, by employing 16S-rRNA gene analysis; this technique holds a great potential in characterizing the microbial diversity of contaminated environments (Nogales et al. 2001). Previously, several studies have been conducted to discern the phylogeny structure of several environment niches (Borneman et al. 1996; Ellis et al. 2003; Kuske et al. 1997; Quirino et al. 2009); however, to best of our knowledge, no studies have been undertaken to reveal the phylogeny structure of this environment. Therefore by analyzing the molecular phylogeny structure of this region, we wish to shed light into predominant microflora associated with such soil samples, and we strongly believe that it will enable researchers in designing better strategy to engineer these microorganisms and their metabolically active genes to combat pollution in such environment.

\section{Materials and methods}

Study areas and soil collection

The Punjab state is classified into three regions: Majha, Malwa and Doaba. Our study area is the Malwa region, which is south to river Satluj approximately between $29^{\circ} 30^{\prime}$ and $31^{\circ} 10^{\prime}$ north latitudes and $73^{\circ} 50^{\prime}$ and $76^{\circ} 50^{\prime}$ east longitudes. The study area comprises the following districts namely Fazilka, Bathinda, Mansa, Moga, Faridkot, Patiala, Sangrur, Barnala, Ferozepur, Muktsar and Ludhiana comprising an area of approximately $32,808 \mathrm{~km}^{2}$ (Mittal et al. 2014). Temperature in Malwa region ranges from $0{ }^{\circ} \mathrm{C}$ in winters to $47{ }^{\circ} \mathrm{C}$ in summers. The sites for the collection of soil samples were chosen on the basis of cancer prevalence in a particular area. We selected six agricultural fields from the different high cancer prone areas of the Malwa region. Samples were collected by the end of January and temperature at the time of sampling was $12{ }^{\circ} \mathrm{C}$. Samples were collected in fresh autoclaved falcon tubes and were kept on dry ice during transportation from collection site to the laboratory, and were stored at $-20{ }^{\circ} \mathrm{C}$ till use.

\section{DNA extraction and purification}

Metagenomic DNA was directly extracted from $0.5 \mathrm{~g}$ of all the six soil samples employing XcelGen Soil gDNA isolation Kit (Xcelris genomics), as per manufacturer's instructions. The extracted DNA was brown in color and was further purified according to the method of Sharma et al. (2007), using Q-Sepharose (Sigma). Q-Sepharose was washed and equilibrated with $10 \mathrm{mM}$ potassium phosphate buffer ( $\mathrm{pH}$ 7.2). Finally, approximately, $500 \mu \mathrm{l}$ of solid washed beads were suspended in $1.5 \mathrm{ml}$ of $10 \mathrm{mM}$ potassium phosphate buffer. After mixing thoroughly, the aliquots of $300 \mu \mathrm{l}$ of Q-Sepharose in buffer were transferred to six eppendorf tubes $(1.5 \mathrm{ml})$ and centrifuged for $1 \mathrm{~min}$ to separate the overlaying buffer. Chromosomal DNA from the six soil samples was added into the centrifuge tubes containing Q-Sepharose beads, and mixed appropriately via inverting the tubes up and down gradually for $15 \mathrm{~min}$. Tubes were kept at room temperature for $5 \mathrm{~min}$. The Humic acids and polyphenolic compounds in the chromosomal preparation bound immediately to the Q-Sepharose. The preparations were centrifuged at $1,000 \times g$ for $1 \mathrm{~min}$. Supernatant containing DNA was saved for further molecular manipulations.

\section{PCR amplification and cloning of $16 \mathrm{~S}$ rRNA}

Purified DNA from all the six soil samples was used as a template for PCR amplification. The pair of primer used for the amplification was $342 \mathrm{~F}$ ( $5^{\prime}$-CTACGGGGGGCAGCAG- $\left.3^{\prime}\right)$ and 806R (5'-GGACTACCGGGGTATCT-3') (Mori et al. 2014) and 27F ( $5^{\prime}$-AGAGTTTGATCMTGGCTCAG- $\left.3^{\prime}\right)$ and 27R (5'-CGGYTACCTTGTTACGAC-3') as potential forward and reverse universal primers, respectively. To amplify the $16 \mathrm{~S}$ rRNA genes, a touchdown PCR was performed in a 
Thermocycler (Veriti, Applied Biosystems) with the following thermal cycling conditions, $94{ }^{\circ} \mathrm{C}, 4 \mathrm{~min}$, followed by 16 cycles of $94{ }^{\circ} \mathrm{C}$ for $50 \mathrm{~s}$, annealing temperature was stepdowns every cycle to $0.3{ }^{\circ} \mathrm{C}$ (from 55 to $50.2{ }^{\circ} \mathrm{C}$ ) followed by extension at $72{ }^{\circ} \mathrm{C}$ for $2 \mathrm{~min}$. The final PCR product was further amplified for another 15 cycles, at an annealing temperature of $50{ }^{\circ} \mathrm{C}$, whereas the denaturation and extension phases were same as mentioned previously. Each $25 \mu \mathrm{l}$ PCR contained $1 \mu \mathrm{l}(0.1 \mu \mathrm{g})$ of total soil DNA, $1 \mu \mathrm{l}$ of each primer $(100 \mu \mathrm{M})$, $25 \mathrm{mM}$ dNTPs (Thermo Scientific), 1 U Taq DNA polymerase (Thermo Scientific) and $1 \times$ Taq reaction buffer (Thermo Scientific). A negative control reaction was also performed (having no DNA template). PCR amplification products were run on a $1.5 \%$ agarose gel stained with ethidium bromide and bands of approximately 500, $900 \mathrm{bp}$ and $1.4 \mathrm{kbp}$ were excised and DNA was purified from gel slices using the XcelGen DNA Gel/PCR Purification kit (Xcelris genomics). The gel-eluted PCR products from all the six soil samples were pooled and cloned into the pGEM-T easy vector (Promega, USA) as per manufacturer's instruction. The plasmid DNA was extracted from the randomly selected positive clones $(\sim 1,000$ random clones were used) employing Hi Yield ${ }^{\mathrm{TM}}$ Plasmid DNA Mini Kit (Real Genomics).

\section{Nucleotide sequencing}

Nearly 150 randomly selected recombinant clones were sequenced for the presence of $16 \mathrm{~S}$ rRNA fragments. The nucleotide sequencing of cloned 16S rRNA genes was performed in an automated DNA sequencer ABI 3730xl (Applied Biosystems). Plasmid DNA preparations were carried out on microtiter plates according to ABI protocol and was used as a template for PCR cycle sequencing (Eppendorf) using the Big DYE Terminator Cycle Sequencing (Applied Biosystems) according to manufacturer's instructions employing a T7 forward and SP6 reverse primer. To confirm the identities of each nucleotide, clones were sequenced twice.

Sequence analysis and construction of phylogenetic tree

The DNA sequences obtained after sequencing were annotated and pasted as word file, and were further searched for \% homology against the gene database at NCBI. Reads were edited by the removal of chimeras using DECIPHER (Wright et al. 2012), low-quality sequences and the formation of contigs using the CAP3 software (Huang and Madan 1999). The partial contigs of the $16 \mathrm{~S}$ rRNA gene were compared to the non-redundant database of sequences deposited at the NCBI using BLASTN (Altschul et al. 1990). Results were used to determine that sequences were in fact from $16 \mathrm{~S}$ rRNA and to determine their degree of similarity to previously known sequences.
Multiple sequence alignment (MSA) was carried out using Clustal W (Thompson et al. 1994) with default settings. Phylogenetic analyses were performed with the Mega programs version 6.06 (Tamura et al. 2013) using the maximum parsimony method (DNA-PARS) with 1,000 bootstrap replicates for the generation of phylogenetic trees. The tree was displayed as radial tree.

AIBIMM (Alignment-independent bilinear multivariate modeling)

In addition to alignment-dependent analysis, a non-alignment-based analysis of microbial community was also carried out via alignment-independent bilinear multivariate modeling (AIBIMM) approach, as described previously (Rudi et al. 2006). The sequences were transformed into multimer frequencies $(n=6)$ by computer program PhyloMode (http://www.matforsk.no/web/sampro.nsf/ downloadE/Microbialcommunity). The multimer frequency data were compressed using principal component analysis (PCA). The starting and end point in the sequences were corrected using the normalize option data in PhyloMode. The two first principal components (PCs) were subsequently used for generating pairwise Euclidean distances for phylogenetic tree construction.

\section{Accession numbers}

The nucleotide sequences described in this study have been submitted to the GenBank database of the NCBI under the Accession Numbers KM260222-KM260292.

\section{Results and discussion}

The 16S rRNA gene analysis has become a valuable tool for studying the phylogenetic relatedness among microorganisms (Janssen 2006). Soil of Malwa region in Punjab (India) is known to be constantly contaminated with heavy metals and pesticides due to long-term agricultural practices in Punjab (Mittal et al. 2014; Blaurock-Busch et al. 2014). In our previous study, we also reported considerable presence of heavy metals and pesticides in the soil sample from this region (manuscript submitted in current science); therefore, we embarked upon studying the microbial diversity of the soil samples from this region to understand the distinctive ecosystem and the role of these microbes might play in maintaining ecosystem processes. To meet our aim, we extracted high-molecular weight metagenomic DNA corresponding to $\sim 23 \mathrm{~kb}$ size that appeared to be brown in color, because of the presence of humic acids and polyphenolic compounds in it. Such contaminants are known to hinder molecular manipulations, i.e. PCR amplification and 
restriction enzyme digestion (Tebbe and Vahjen 1993). The DNA was, therefore, purified according to the method of Sharma et al. (2007) that resulted in pure colorless DNA (data not shown). Subsequently, the purified DNA was used for PCR amplification and cloning. Amplification of $16 \mathrm{~S}$ rRNA genes from the environment DNA was carried out employing touchdown PCR that resulted in amplification of gene at three distinctive positions corresponding to $\sim 500$, $900 \mathrm{bp}$ and $1.4 \mathrm{kbp}$. The PCR-amplified products were gel eluted and cloned into pGEM-T easy vector, thus a library representing $\sim 1,000$ clones was prepared. The plasmid DNA was extracted from the randomly selected clones, followed by sequencing of one-hundred and fifty recombinant clones. It is a well-studied fact that chimeras can result from the amplification of DNA directly extracted from an environmental sample (Wintzingerode et al. 1997). Among the 150 sequences analyzed, more than 40 appeared to be putative chimeric artifacts (vector sequences) which were detected using DECIPHER, and nearly 39 clones were of low-quality sequences, and hence were excluded from subsequent analysis. Finally, $\sim 71$ nucleotide sequences were analyzed for further studies. The recovered clones showed abundance according to group affiliation that included members of all the major phyla, commonly present in soil, as demonstrated in Fig. 1. The chimera-free and high-quality sequences were blasted in the GenBank (http://www. ncbi.nlm.nih.gov) using Blast $\mathrm{N}$ program. Based on similarity, the sequences were selected for the construction of the phylogenetic tree. To find out the phylogenic relatedness

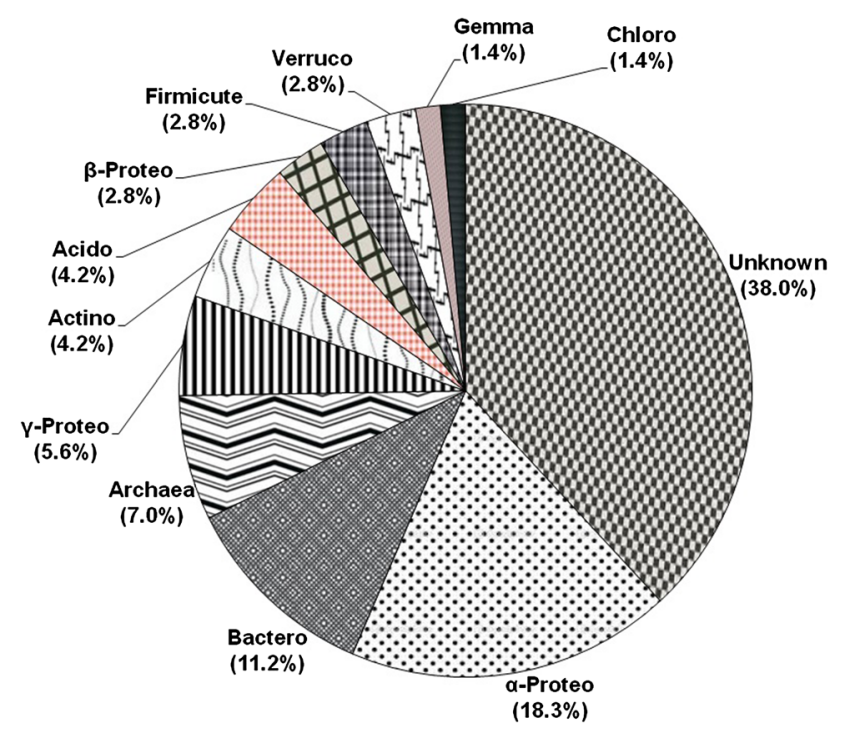

Fig. 1 The percentage distribution of 16S rRNA genes. Each sector indicates percentage of clones within each phylogenetic group: unknown soil bacteria (unknown), $\alpha$-Proteobacteria ( $\alpha$-Proteo), Bacteroidetes (Bactero), Archaea, $\gamma$-Proteobacterium ( $\gamma$-Proteo), Actinobacteria (Actino), Acidobacteria (Acido), $\beta$-Proteobacterium ( $\beta$-Proteo), Firmicute, Verrucomicrobia (Verruco), Gemmatimonadetes (Gemma), Chloroflexi (Chloro) among the clones, we did both alignment-dependent and alignment-independent analysis. Phylogenetic tree was constructed based on MSA (multiple sequence alignment) and was analyzed via maximum parsimony. The tree was displayed as a radial tree (Fig. 2). In addition, a multivariate statistical approach was used to further explore the patterns in the sequencing data obtained. The prime objective behind using PCA was to gather the major information of the data and expressing it as a set of new orthogonal variables (principal components). The data gathered employing alignment-independent method provided a more comprehensive interpretation of the relationship among microorganisms. From the PCA plot analysis (Fig. 3), it becomes evident that there are $10.94 \%$ variants in the $\mathrm{PC} 1$ and $7.06 \%$ variants in the PC2. The pattern of points displayed in the plot clearly points towards the level of similarity between different groups of microorganisms which is further confirmed by the cluster formation. The points displayed outside the clusters distinctly reflect their difference from clustered microorganisms. All the clusters represent miscellaneous population of microbes. Interestingly, Archaeal population shows similarity with bacterial population. Phylogenetic tree (Fig. 2) demonstrated two major and several minor groups. Nearly $62 \%$ sequences reported in the study shared $90-95 \%$ similarity to cultivable bacterial groups; interestingly, $38 \%$ sequences showed no homology to the cultivable bacterial groups and represent novel bacterial groups. A few (7.0\%) sequences of archaeal origin were also detected from this community that indicates change in evolution pattern of archaea. Previously, they were considered to be the domain of extreme environments. Previous studies have also documented their presence in non-extreme environments including marine (DeLong et al. 1994), terrestrial (Kudo et al. 1997), and in metal-contaminated ecosystems (Sandaa et al. 1999a). This implies that presence of archaea may have important ecological consequences in non-extreme habitats also. The majority of the bacteria discovered belong to two major phylums: the Proteobacteria $(26.7 \%)$ and the Bacteroidetes $(11.2 \%)$. Other minor groups were also observed that correspond to Acidobacteria (4.2\%), Actinobacteria (4.2\%), Firmicutes (2.8\%), Verrucomicrobia (2.8\%), Gemmatimonadetes (1.4\%) and Chloroflexi (1.4\%). Furthermore, several unidentified uncultured clones of novel bacterial origin (38.0 \%) (Fig. 1) were also recovered. Among all the phylums identified, phylums Actinobacteria and Firmicutes constituted grampositive bacteria (Rappe and Giovannoni 2003). From literature, it becomes evident that the phylums mainly found in soils are Proteobacteria, Actinobacteria, Acidobacteria and Verrucomicrobia (Janssen 2006). Analysis of the clones from bacterial origin revealed predominantly the presence of Proteobacteria, a phylum whose presence is well documented in contaminated sites (Ellis et al. 2003; Rastogi et al. 


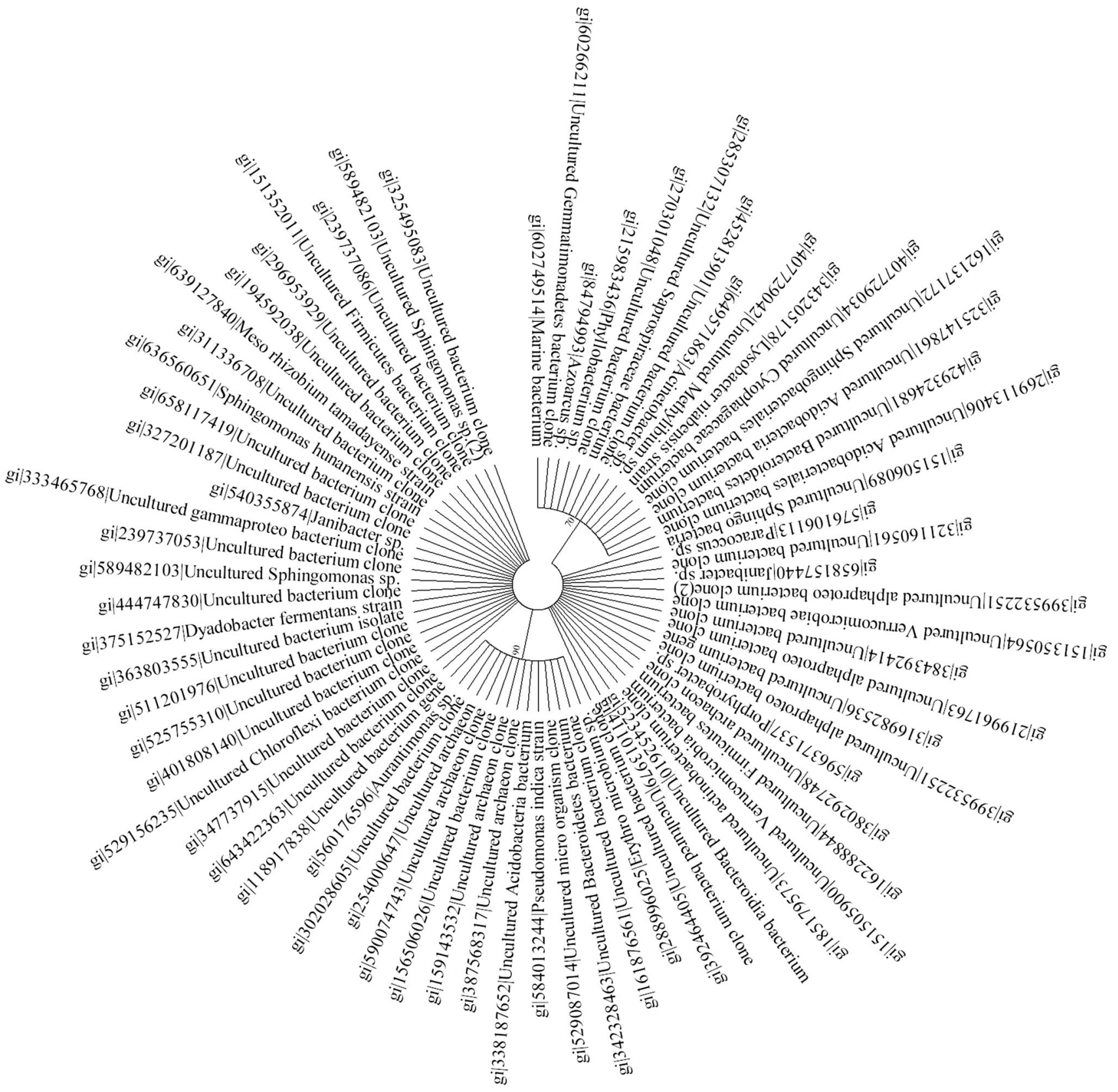

Fig. 2 Phylogenetic tree of annotated sequences of 16S rRNA gene cloned directly from environmental DNA. The analysis involved 71 nucleotide sequences aligned with Clustal W (Thompson et al. 1994) and the evolutionary history was inferred by maximum parsimony

2010). Another major groups reported to be abundantly present in polluted soil are Actinobacteria and Acidobacteria (Briceno et al. 2012; Paul et al. 2006; Ward et al. 2009); however, we observed their insignificant presence in the present study. In contrast to this these species are reported to be abundantly present in the non-contaminated samples (Sandaa et al. 1999b; Sheik et al. 2012). Next, among $\alpha, \beta$, $\gamma, \delta, \varepsilon$ subdivision of Proteobacteria, we mainly observed $\alpha$ Proteobacteria, which is well correlated to previous studies method from MEGA6 programs (Tamura et al. 2013) using 1,000 bootstrap replicates. Unknown sequences are represented by a clone number

conducted on metal-contaminated soil of Braunschweig, Germany (Sandaa et al. 1999b). In contrast, Joynt et al. (2006) identified $\delta$ Proteobacteria along with $\alpha, \beta, \gamma$ Proteobacteria in heavy metal-contaminated soil. The $\alpha$-proteobacterial clones identified were of Sphingomonas, Mesorhizobium tamadayense, Phyllobacterium, Porphyrobacter, Erythromicrobium, Paracoccus and Aurantimonas. Under $\gamma$-proteobacterium, we observed sequence of Lysobacter niabensis, Pseudomonas indica and Acinetobacter 


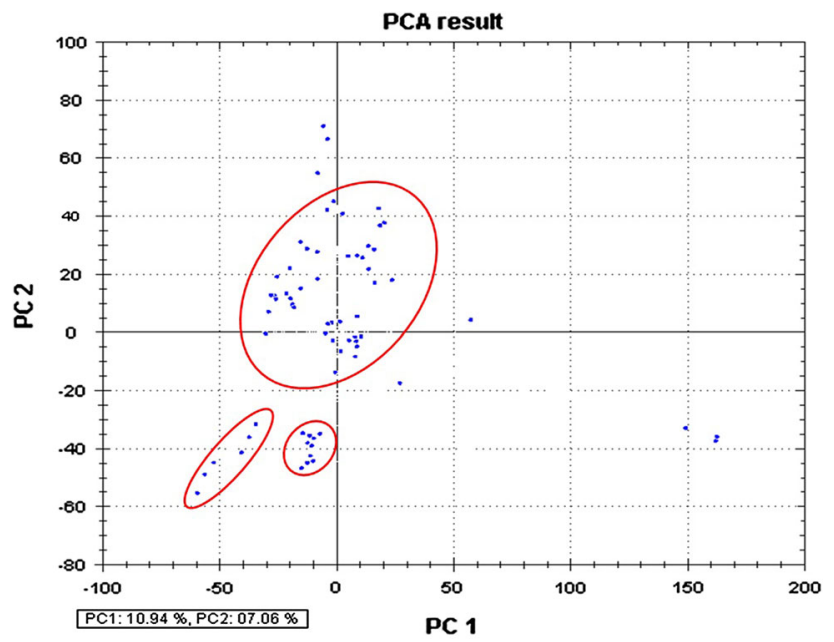

Fig. 3 PCA analysis for soil bacterial community. The first principal component (PC1) is the line explaining $10.94 \%$ variance. The second principal component $(\mathrm{PC} 2)$ is the line that explains $07.06 \%$ variance

origin. Among all, Acinetobacter is an important soil bacterium and has the potential to remove a wide range of pollutants (Abdel-El-Haleem 2003). Genus Azoarcus and Methylibium found in the study belong to $\beta$-proteobacterium. Additionally, the second most abundant phylum observed in this study was Bacteroidetes that harbor Sphingobacteria, Saprospiraceae, Cytophagaceae, Dyadobacter fermentans. Presence of Bacteroidetes has been previously reported in heavy metal-contaminated soils and sediments (Akob et al. 2008; Brodie et al. 2006; Ellis et al. 2003). The main feature of this bacterial community study is the abundant presence of uncultivable bacteria (38\%), and Proteobacteria which is one of the most abundant soil bacteria (Spain et al. 2009). Previous studies conducted on non-polluted environment samples have demonstrated variation in abundance of Acidobacteria, Bacteroidetes, Firmicutes and Proteobacteria (beta, gamma and delta) along with fewer phyla Nitrospira, Deferribacteres, Chloroflexi. The abundant presence of $\alpha$ proteobacteria $(18.2 \%)$ in our study conducted on contaminated soil samples is well correlated to previous studies where they are shown to be present abundantly in contaminated soil, and scarcely reported in non-contaminated soil (Dhal et al. 2011; Sandaa et al. 1999b; Sheik et al. 2012). In addition to this Sandaa et al. (1999b), reported that the sequences from Gram-positive bacteria with a high DNA $\mathrm{G}+\mathrm{C}$ content were more in soil with low metal inputs. These studies clearly demonstrate that microbial diversity strongly varies in two environments (contaminated and non-contaminated soil). Interestingly, identification of Sphingomonas from variety of contaminated environments is well documented, where they are implicated in degradation of numerous pollutants such as herbicides (Adkins 1999), Polycyclic Aromatic Hydrocarbons (PAHs) (Pinyakong et al. 2003), insecticides (Yu et al. 2013), heavy metals (Chien et al. 2008). This unique feature of the Sphingomonas bacterium may be attributed to molecular structure of its cell surface, which is reported to be more hydrophobic compared to other Gram-negative bacteria, due to the presence of glyco-sphingolipids instead of lipo-polysaccharides, hence has high ability to degrade many hydrophobic compounds or pollutants (Kawahara et al. 1999), and make it vital bacteria in bioremediation from various contaminated sites, which is also now becoming an intriguing area in research. Similarly, other bacteria belonging to Alphaproteobacteria also have appreciable biodegradative potential. The Paracoccus species are also implicated in biodegradation of various insecticides used in agricultural fields, such as chlorpyrifos as it can effectively degrade pyridine, a compound involved in the synthesis of chlorpyrifos (Lin et al. 2010; Xu et al. 2008) and fipronil (Kumar et al. 2012). Similarly, Mezorhizobium species are also implicated in chorpyrifos degradation (Jabeen et al. 2014). Furthermore, we did not observe Deltaproteobacteria in the present study, whereas they were reported to be quite abundant in the non-contaminated site (Dhal et al. 2011). The biodegradative capabilities of these bacterial consortia become more effective when they act together in association with each other (Fritsche and Hofrichter 2000) and culture-independent molecular approach enables us to identify such a huge diversity of microbial consortium which plays a major role in ecosystem processes. Despite high level of contamination in the study area, the remarkable microbial diversity observed stipulate versatility and adaptability of microorganisms to endure such environments. Altogether, investigation of the polluted soil samples employing cultureindependent approach revealed important bacterial groups which could serve as a catalyst for future bioremediation studies. Our future goal is to sequence and characterize the metatranscriptome of the microbes present in the soil, and to provide functional insights into important metabolically active genes involved in degradation of these pollutants.

Acknowledgments Dr. PKS would like to thank Science and Engineering Research Board New Delhi for financial assistance conferred to him under Young scientist scheme (FTYS) No. SB/YS/ LS-63/2013. All the authors declare no conflict of interests regarding publishing this article to this journal.

Open Access This article is distributed under the terms of the Creative Commons Attribution License which permits any use, distribution, and reproduction in any medium, provided the original author(s) and the source are credited.

\section{References}

Abdel-El-Haleem D (2003) Acinetobacter: environmental and biotechnological applications. Afr J Biotechnol 2:71-74

Adkins A (1999) Degradation of the phenoxy acid herbicide diclofopmethyl by Sphingomonas paucimobilis isolated from a Canadian prairie soil. J Ind Microbiol Biotechnol 23:332-335 
Akob DM, Mills HJ, Ghiring TM, Kerkhof L, Stucki JW, Anastacio AS, Chin KJ, Kusel K et al (2008) Functional diversity and electron donor dependence of microbial populations capable of $\mathrm{U}(\mathrm{VI})$ reduction in radionuclide-contaminated subsurface sediments. Appl Environ Microbiol 74:3159-3170

Alexander M (1977) Introduction to soil microbiology. Wiley, New York

Altschul SF, Gish W, Miller W, Myers EW, Lipman DJ (1990) Basic local alignment search tool. J Mol Biol 215:403-410

Amann RI, Ludwig W, Schleifer KH (1995) Phylogenetic identification and in situ detection of individual microbial cells without cultivation. Microbiol Rev 59:143-169

Blaurock-Busch E, Busch YM, Friedle A, Buerner H, Parkash C, Kaur A (2014) Comparing the metal concentration in the hair of cancer patients and healthy people living in the Malwa region of Punjab, India. Clin Med Insights Oncol 8:1-13

Borneman J, Skroch PW, O'Sullivan KM, Palus JA, Rumjanek NG, Jansen JL, Nienhuis J, Triplett EW (1996) Microbial diversity of an agricultural soil in Wisconsin. Appl Environ Microbiol 62:1935-1943

Briceno G, Fuentes MS, Palma G, Jorquera MA, Amoroso MJ, Diez MC (2012) Chlorpyrifos biodegradation and 3,5,6-trichloro-2pyridinol production by Actinobacteria isolated from soil. Int Biodeter Biodegr 73:1-7

Brodie EL, DeSantis TZ, Joyner DC, Baek SM, Larsen JT, Andersen GL, Hazen TC, Richardson PM et al (2006) Application of a high-density oligonucleotide microarray approach to study bacterial population dynamics during uranium reduction and reoxidation. Appl Environ Microbiol 72:6288-6298

Chien C, Kuo Y, Chen C, Hung C, Yeh C, Yeh W (2008) Microbial diversity of soil bacteria in agricultural field contaminated with heavy metals. J Environ Sci 20:359-363

Daniel R (2005) The metagenomics of soil. Nat Rev Microbiol $3: 470-478$

DeLong EF, Wu KY, Prezelin BB, Jovine RV (1994) High abundance of Archaea in Antarctic marine picoplankton. Nature 371:695-697

Dhal PK, Islam E, Kazy SK, Sar P (2011) Culture-independent molecular analysis of bacterial diversity in uranium-ore/-mine waste-contaminated and non-contaminated sites from uranium mines 3. Biotech 1:261-272

Diaz E (2004) Bacterial degradation of aromatic pollutants: a paradigm of metabolic versatility. Int Microbiol 7:173-180

Ellis RJ, Morgan P, Weightman AJ, Fry JC (2003) Cultivation dependent and independent approaches for determining bacterial diversity in heavy-metal-contaminated soil. Appl Environ Microbiol 69:3223-3230

Fritsche W, Hofrichter M (2000) Aerobic degradation by microorganisms. Klein J(ed) Environmental processes II-soil decontamination. Wiley, Weinheim, pp 146-155

Handelsman J, Rondon MR, Brady SF, Clardy J, Goodman RM (1998) Molecular biological access to the chemistry of unknown soil microbes: a new frontier for natural products. Chem Biol 5:R245-R249

Huang X, Madan A (1999) CAP3: a DNA sequence assembly program. Genome Res 9:868-877

Hugenholtz P, Pace NR (1996) Identifying microbial diversity in the natural environment: a molecular phylogenetic approach. Trends Biotechnol 14:190-197

Jabeen H, Iqbal S, Anwar S (2014) Biodegradation of chlorpyrifos and 3,5,6-trichloro-2-pyridinol by a novel rhizobial strain Mesorhizobium sp. HN3. Water Environ J. doi:10.1111/wej. 12081

Janssen PH (2006) Identifying the dominant soil bacterial taxa in libraries of 16S rRNA and 16S rRNA genes. Appl Environ Microbiol 72:1719-1728
Joynt J, Bischoff M, Turco R, Konopka A, Nakatsu CH (2006) Microbial community analysis of soils contaminated with lead, chromium and petroleum hydrocarbons. Microb Ecol 51:209-219

Kawahara K, Kuraishi H, Zahringer U (1999) Chemical structure and function of glycosphingolipids of Sphingomonas spp. and their distribution among members of the alpha- 4 subclass of Proteobacteria. J Ind Microbiol Biotechnol 23:408-413

Kudo Y, Shibata S, Miyaki T, Aono T, Oyaizu H (1997) Peculiar archaea found in Japanese paddy soils. Biosci Biotechnol Biochem 61:917-920

Kumar R, Singh B, Gupta VK (2012) Biodegradation of fipronil by Paracoccus sp. in differnt types of soil. Bull Environ Contam Toxicol 88:781-797

Kuske CR, Barns SM, Busch JD (1997) Diverse uncultivated bacterial groups from soils of the arid southwestern United States that are present in many geographic regions. Appl Environ Microbiol 63:3614-3621

Lin Q, Donghui W, Jianlong W (2010) Biodegradation of pyridine by Paracoccus sp. KT-5 immobilized on bamboo-based activated carbon. Bioresour Technol 101:5229-5234

Mittal S, Kaur G, Vishwakarma GS (2014) Effects of environmental pesticides on the health of rural communities in the Malwa region of Punjab (India): a review. Hum Ecol Risk Assess 20:366-387

Mori H, Maruyama F, Kato H, Toyoda A, Dozono A, Ohtsubo Y, Nagata Y, Fujiyama A et al (2014) Design and experimental application of a novel non-degenerate universal primer set that amplifies prokaryotic $16 \mathrm{~S}$ rRNA genes with a low possibility to amplify eukaryotic rRNA genes. DNA Res 21:217-227

Nogales B, Moore ER, Llobet-Brossa E, Rossello-Mora R, Amann R, Timmis KN (2001) Combined use of $16 \mathrm{~S}$ ribosomal DNA and $16 \mathrm{~S}$ rRNA to study the bacterial community of polychlorinated biphenyl-polluted soil. Appl Environ Microbiol 67:1874-1884

Paul D, Pandey G, Meier C, van der Meer JR, Jain RK (2006) Bacterial community structure of a pesticide-contaminated site and assessment of changes induced in community structure during bioremediation. FEMS Microbiol Ecol 57:116-127

Pinyakong O, Habe H, Omori T (2003) The unique aromatic catabolic genes in sphingomonads degrading polycyclic aromatic hydrocarbons (PAHs). J Gen Appl Microbiol 49:1-19

Quirino BF, Pappas GJ, Tagliaferro AC, Collevatti RG, Neto EL, da Silva MR, Bustamante MM, Kruger RH (2009) Molecular phylogenetic diversity of bacteria associated with soil of savanna-like Cerrado vegetation. Microbiol Res 164:59-70

Rappe MS, Giovannoni SJ (2003) The uncultured microbial majority. Annu Rev Microbiol 57:369-394

Rastogi G, Osman S, Vaishampayan PA, Andersen GL, Stetler LD, Sani RK (2010) Microbial diversity in uranium mining impacted soils as revealed by high-density $16 \mathrm{~S}$ microarray and clone library. Microb Ecol 59:94-108

Riesenfeld CS, Schloss PD, Handelsman J (2004) Metagenomics: genomic analysis of microbial communities. Annu Rev Genet 38:525-552

Rudi K, Zimonja M, Naes T (2006) Alignment independent bi-linear multivariate modeling (AIBIMM) for global analyses of $16 \mathrm{~S}$ rRNA phylogeny. Int J Syst Evol Microbiol 56:1565-1575

Sandaa RA, Enger O, Torsvik V (1999a) Abundance and diversity of Archaea in heavy-metal contaminated soils. Appl Environ Microbiol 65:3293-3297

Sandaa RA, Torsvik V, Enger O, Daae FL, Castberg T, Hahn D (1999b) Analysis of bacterial communities in heavy metalcontaminated soils at different levels of resolution. FEMS Microbiol Ecol 30:237-251

Sharma PK, Capalash N, Kaur J (2007) An improved method for single step purification of metagenomic DNA. Mol Biotechol 36:61-63 
Sheik CS, Mitchell TW, Rizvi FZ, Rehman Y, Faisal M, Hasnain S, Mclnerny MJ, Krumholz LR (2012) Exposure of soil microbial communities to chromium and arsenic alters their diversity and structure. PLoS One 7(6):e40059

Spain AM, Krumholz LR, Elshahed MS (2009) Abundance, composition, diversity and novelty of soil Proteobacteria. ISME J 3:992-1000

Tamura K, Stecher G, Peterson D, Filipski A, Kumar S (2013) MEGA6: molecular evolutionary genetics analysis version 6.0. Mol Biol Evol 30:2725-2729

Tebbe CC, Vahjen W (1993) Interference of humic acids and DNA extracted directly from soil in detection and transformation of recombinant DNA from bacteria and yeast. Appl Environ Microbiol 59:2657-2665

Thompson JD, Higgins DG, Gibson TJ (1994) Clustal W: improving the sensitivity of progressive multiple sequence alignment through sequence weighting, position specific gap weighting and weight matrix choice. Nucleic Acids Res 22:4673-4680

Ward DM, Weller R, Bateson MM (1990) 16S rRNA sequences reveal numerous uncultured microorganisms in a natural community. Nature 345:63-65
Ward NL, Challacombe JF, Janssen PH, Henrissat B, Coutinho PM, Wu M, Xie G, Haft DH et al (2009) Three genomes from the phylum Acidobacteria provide insight into the lifestyles of these microorganisms in soils. Appl Environ Microbiol 75:2046-2056

Wintzingerode FV, Gobel UB, Stackebrandt E (1997) Determination of microbial diversity in environmental samples: pitfalls of PCRbased rRNA analysis. FEMS Microbiol Rev 21:213-229

Wright ES, Yilmaz LS, Noguera DR (2012) DECIPHER, a searchbased approach to chimera identification for $16 \mathrm{~S}$ rRNA sequences. Appl Environ Microbiol 78:717-725

Xu G, Zheng W, Li Y, Wang S, Zhang J, Yan Y (2008) Biodegradation of chlorpyrifos and 3,5,6-trichloro-2-pyridinol by a newly isolated Paracoccus sp. strain TRP. Int Biodeter Biodegr 62:51-56

Yu FB, Shan SD, Luo LP, Guan LB, Qin H (2013) Isolation and characterization of a Sphingomonas sp. strain F-7 degrading fenvalerate and its use in bioremediation of contaminated soil. J Environ Sci Health 48:198-207 